\title{
Surviving Marital Relationship During the COVID-19 Pandemic: A Systematic Review on Marital Conflict
}

\author{
Shinta Wisyaningrum ${ }^{1}$, Ignasia Epifani ${ }^{2}, \&$ Annastasia Ediati $^{3 *}$ \\ ${ }^{1}$ Fakultas Psikologi, Universitas Diponegoro, Semarang, Indonesia \\ ${ }^{2}$ Fakultas Psikologi, Universitas Diponegoro, Semarang, Indonesia \\ ${ }^{3}$ Fakultas Psikologi, Universitas Diponegoro, Semarang, Indonesia \\ "Corresponding author.Email: ediati@lecturer.undip.ac.id
}

\begin{abstract}
Pandemic COVID-19 brings tremendous impact on families, particularly on marital relationship. We reported finding on systematic review concerning how marriages survive against marital conflict during COVID-19 pandemic. Using the Google Scholar database, we searched articles using the following keywords marital conflict AND pandemic. Subsequently, articles selection was done using the following inclusion criteria: original article, written in English, and full-text available. From 86 articles that had been found, there were 6 articles that met the selection criteria and eligible for review. Data analysis reveal that marital conflict led to reduced intimacy then subsequently increase domestic violence. Working couples, particularly who have children whom following school from home, they reported increased stress at home. However, work-family conflict is low and manageable if social support from family members is available. Childless couples reported higher marital satisfaction than couples with children. Gender gap are wider as domestic responsibilities were not distributed fairly between husbands and wives which in turn influence marital relationship and put either husbands or wives at risk for being victims of domestic violence. We conclude that during COVID-19 pandemic, couple encountered major challenges that need to be addressed in healthy manner to survive their marriage. Psychoeducation program for couples is needed in times of crisis to prevent the escalated problems and to help couples build supportive marital relationships.
\end{abstract}

Keywords: Marital Conflict, Marital Relationship, COVID-19 Pandemic.

\section{INTRODUCTION}

Marriage is one of the most important dimensions of life in human life. Household life is not always without conflicts or problems, but the most important thing is how each partner is able to overcome every gravel problem that occurs. If the problems that occur are not resolved immediately, it will cause a prolonged conflict. Marital conflict is a condition where a husband and wife experience problems in their marriage and this situation can be seen from their behavior that tends to be less harmonious when conflict is occurring [1].

Marital life is currently being affected by a virus that is being discussed around the world, namely the coronavirus 19 (COVID-19). This virus was first discovered in Wuhan, China's Hubei province in 2019 and is so dangerous that it causes death. Several health protocols have been announced and are required to comply with these regulations. Even though the coronavirus has just emerged, the impact of the pandemic affects all sectors, such as health, socio-economy, and family. The World Health Organization (WHO) has imposed social or psychological distancing to a lockdown for not having social interactions, this effort is made as an effort to stop its spread. The intensity of meeting husband and wife and children for almost 24 hours because they have to stay at home will have different effects for each individual. This condition wants to explain whether the relationship between a partner and family improves or worsens during a pandemic. 
Parental work that is done from home or work from home, including housewives who take care of the house and children who go to school online, is a new condition that requires adjustment for all parties. Relationships that exist, challenges, quality of care, family needs during a pandemic can become problems that lead to spouse and family conflicts if there is no resolution. In addition, the COVID-19 pandemic with various impacts affects the condition of partners, requiring parents who work to experience balance and injustice in how partners survive conflict, how partners cope with situations that require cooperation, mutual understanding so that conflicts in marriage can be minimized.

\section{METHOD}

This is a systematic review study that had been carried out by referring to the guideline for conducting systematic review for psychological research [2] and using the PRISMA guideline [3]. We searched the following keywords in Google Scholar database: "marital conflict" AND pandemic and keywords for additional documents with the same database, "marital conflict" OR "marital relationship" AND pandemic.

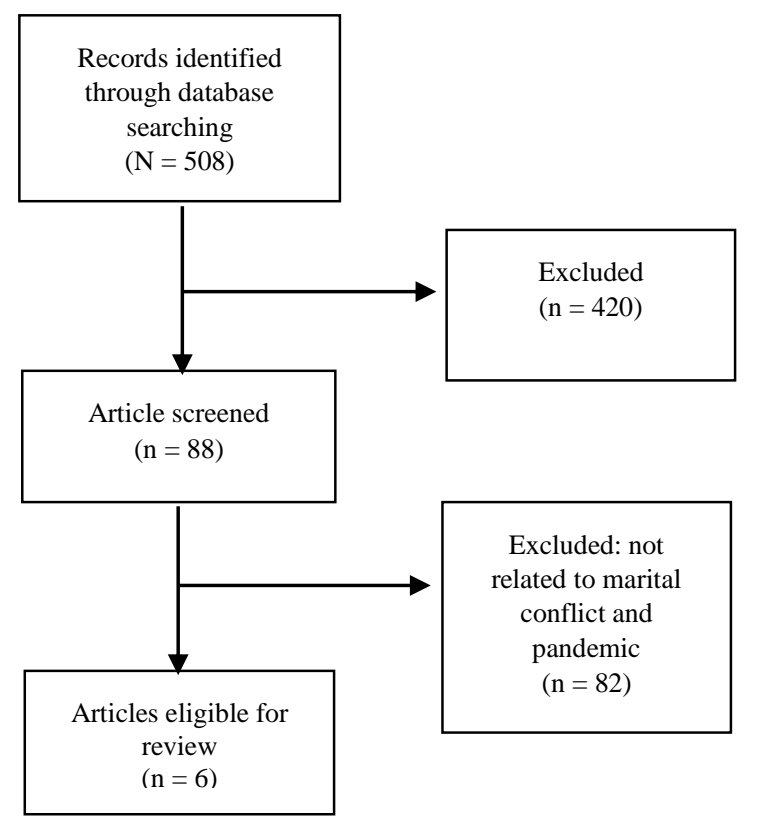

Figure 1. Article selection flowchart

The inclusion criteria were original articles, written in English, available full text, published in the year 2020, and articles related to marital conflicts, marital relationships and pandemics. The article selection process can be seen in Figure 1.

\section{RESULT}

The purpose of this study is to describe how marital and family relationships can survive during the COVID-19 pandemic. Based on six articles we reviewed (see Table 1), we summarized conflicts in marriage and how relationships with spouses and families survive during pandemic conditions. These studies had been conducted in Singapore, Canada, Spain and Australia.

Marital relationship during lockdown brings changes to spouses and families, either couples who have children or not. During the lockdown, family relationships were impacted, either improved or worsened [7]. Improvement in the family relationship during lockdown as in a better communication, emotional expression, team spirit, and a balance between individual and shared needs. In contrary, decreased in family relationships were identified from the reported loneliness and distant couples or families, negative expectations, frequent conflicts, and the imbalanced between individual needs and family demand. Couples who do not have children reported same or even better marital relationship during the lockdown rather than before lockdown [7].

Pandemic conditions put individuals in a condition that enable them to be resilient. Resilience is the individual's ability to cope effectively and bounce back from adversity [20]. Every individual has resilience, but the level of resistance is determined by the interaction between the individual and environmental [21]. Since the pandemic may impact mental health in the long term, parental resilience in necessary to build resilience for children [22]. A high level of resilience was associated with low levels of stress, anxiety, and depression [8]. Loneliness is a major contributor to mental health outcomes. Increased extraversion is associated with increased resistance. Previous studies highlight the link of loneliness and poor mental health conditions [23] and increased mortality [24]. The relationship between resilience and depression is influenced by the level of partner's support. Increasing interactions with partner can help reduce stress and increase resilience during the pandemic. 
Table 1. Data extraction results

\begin{tabular}{|c|c|c|c|}
\hline No. & Study focus & Participants and methods & Results \\
\hline 1 & $\begin{array}{l}\text { Lockdown affects the work } \\
\text { family balance (WFB) } \\
\text { because parents work from } \\
\text { home while caring for } \\
\text { children so that it has an } \\
\text { impact on parenting and } \\
\text { marital relationship [4] }\end{array}$ & $\begin{array}{l}258 \text { parents; Singaporean or } \\
\text { permanent residence. } \\
\text { Online survey }\end{array}$ & $\begin{array}{l}\text { Parents with low WFB reported parenting } \\
\text { stress and increased marital conflict. } \\
\text { Support from couples in the form of } \\
\text { assistance in completing domestic } \\
\text { responsibilities can maintain marital } \\
\text { relationship }\end{array}$ \\
\hline 2. & $\begin{array}{l}\text { Parenting } \\
\text { challenges, and familities, } \\
\text { needs during a pandemic } \\
{[5]}\end{array}$ & $\begin{array}{l}656 \text { primary caregivers (e.g. } \\
\text { mother, father, adopted } \\
\text { parents). } \\
\text { Online survey on "parenting } \\
\text { during pandemic" (April } 4- \\
28,2020 \text { ) }\end{array}$ & $\begin{array}{l}\text { Unmet care needs and highlighting } \\
\text { parents who are unable to manage } \\
\text { psychological stress, limited social } \\
\text { support and unstructured time between } \\
\text { partners. Focused efforts are needed to } \\
\text { deal with caregiver mental health to } \\
\text { protect children's health during a } \\
\text { pandemic. Focused efforts are needed to } \\
\text { deal with caregiver mental health to } \\
\text { protect children's health during a } \\
\text { pandemic }\end{array}$ \\
\hline 3. & $\begin{array}{l}\text { Do women and men share } \\
\text { the same workload? } \\
\text { Can inequities in the } \\
\text { division of labour endanger } \\
\text { the relationship with } \\
\text { couple? [6] }\end{array}$ & $\begin{array}{l}\text { Couples with young } \\
\text { children }(\mathrm{N}=157) \\
\text { longitudinal study }\end{array}$ & $\begin{array}{l}\text { A pandemic can disrupt gender equality, } \\
\text { strengthen an unfair division of labor, and } \\
\text { thus disrupt the welfare of women's } \\
\text { relationships. Having some private time } \\
\text { with your partner can reduce problems } \\
\text { and increase marital satisfaction. Fair } \\
\text { division of labor is essential to protect the } \\
\text { health and well-being of women (and } \\
\text { men) which is exacerbated by the } \\
\text { lockdown. }\end{array}$ \\
\hline 4. & $\begin{array}{l}\text { Did spouse and family } \\
\text { relationships improve or } \\
\text { worsen during lockdown? } \\
{[7]}\end{array}$ & $\begin{array}{l}407 \text { adults aged } 18 \text { or older, } \\
\text { live in Spain, live with } \\
\text { children, live with children } \\
\text { in custody due to parents' } \\
\text { divorce. } \\
\text { Online survey using } \\
\text { Facebook dan other social } \\
\text { media platforms }\end{array}$ & $\begin{array}{l}\text { The dynamics of families and couples } \\
\text { change during the lockdown. Couples } \\
\text { have better communication, better } \\
\text { emotional expression and teamwork, and } \\
\text { have a balance between individual and } \\
\text { partner needs. Conflicts with spouse } \\
\text { decrease due to the presence of children in } \\
\text { the family. Maintaining relationship with } \\
\text { spouse can improve marital relationship. }\end{array}$ \\
\hline 5. & $\begin{array}{l}\text { Investigating the } \\
\text { relationship between } \\
\text { resilience and mental health } \\
\text { in a large sample of parents } \\
\text { [8] }\end{array}$ & $\begin{array}{l}2110 \text { parents with children } \\
\text { aged } 0-18 \text {, Australia. } \\
\text { longitudinal cohort study }\end{array}$ & $\begin{array}{l}\text { The relationship between resilience and } \\
\text { depression was influenced by the level of } \\
\text { partner support }\end{array}$ \\
\hline 6. & $\begin{array}{l}\text { Do negotiating goal } \\
\text { conflicts is associated to } \\
\text { goal outcomes (progress, } \\
\text { confidence, motivation)? } \\
\text { what strategies partners use } \\
\text { during pandemic to }\end{array}$ & $\begin{array}{l}200 \text { adults for quantitative } \\
\text { study; } 48 \text { adults for } \\
\text { qualitative study. } \\
\text { cross-sectional study; } \\
\text { mixed method }\end{array}$ & $\begin{array}{l}\text { Goal conflict is relatively low during a } \\
\text { pandemic and participants are often able } \\
\text { to negotiate a conflict of objectives which } \\
\text { results in better goal outcomes. } \\
\text { Goal conflict is relatively low during a }\end{array}$ \\
\hline
\end{tabular}




\begin{tabular}{|l|l|l|}
\hline $\begin{array}{l}\text { negotiate the conflicted } \\
\text { goals? [9] }\end{array}$ & $\begin{array}{l}\text { pandemic. Conflict negotiation is carried } \\
\text { out by couples with communication } \\
\text { characteristics such as mutual respect, } \\
\text { providing emotional needs, focusing on } \\
\text { practical needs such as practical solutions, } \\
\text { giving time to partners if they feel upset. } \\
\text { Couples can often negotiate a conflict of } \\
\text { goals that results in better goal outcomes. }\end{array}$ \\
\hline
\end{tabular}

During the pandemic, couples show interdependency on one another. Couples often spend long periods of time together and few outside resources are available, allowing conflicts between partners to arise during coping with demands due to the pandemic. This conflict can damage the relationship if solution is not provided. Higher conflict in a relationship can led to a problematic relationship, particularly marital relationship [25]. Therefore, couples are encouraged to reduce conflict in order to reduce stress.

Another way to negotiate conflicts between couples is to prioritize goals associated with outcome and the strategies that are used by couples during a pandemic to negotiate a conflict [9]. The goalconflict negotiation is directed to manage a new condition of parenting, working from home, and the possibility of one or both partners not working. The goal conflict is relatively low during the pandemic [9]. Couple may use the following strategies to manage goal-conflict during the pandemic: respectful communication, discussion, fulfilling the emotional needs, focusing on practical needs i.e., practical solution, give time alone for partner when feeling annoyed. Couples who frequently negotiate conflict of purpose can produce better goals.

\subsection{Conclusion}

The COVID-19 pandemic has an impact on human life. Various problems such as childcare related to work from home, quality of care, gender issues in the division of domestic work roles, how marriage improved or worsened during a pandemic, strategies in conflict negotiation and how couples can cope with all the problems during a pandemic emerge during the pandemic. This paper highlight efforts that spouses and families can make to minimize marital conflict and maintain marital relationships, by increasing the ability to cope with problems. In dealing with marital conflict, one should try to apply the following strategies, such as communication with mutual respect, discussion, providing emotional needs, focusing on practical needs such as practical solutions, giving time to partners if they are upset so that the dynamics of family and partners can be well established despite problems. Spouse support is pivotal, particularly in caring children sharing domestic responsibilities. Moreover, the mental health of primary caregivers should also be considered to maintain children's mental health during the pandemic.

\section{AUTHORS' CONTRIBUTIONS}

SW and AE designed the study, drafting and finalizing the manuscript. IE and SW involved in data search, data analysis, drafting and finalizing the paper.

\section{ACKNOWLEDGMENTS}

We thanked Fakultas Psikologi Universitas Diponegoro for supporting the study. We declared no conflict of interests.

\section{REFERENCES}

[1] F. Giudici, E. Widmer, P. Ghisletta. A sociological assessment of conjugal conflict. Sociologia, Problemas e Práticas. 1(67) (2011) 9-21

[2] L.D. Carvalho, G. Pianowski, M.A. Santos. Guidelines for conducting and publishing systematic reviews in Psychology. Th. Methods Psychol. 36 (2019) DOI: https://doi.org/10.1590/1982$0275201936 \mathrm{e} 180144$.

[3] D. Moher, A. Liberati, J. Tetzlaff, D.G. Altman, Prisma Group. Preferred reporting items for systematic reviews and meta-analyses: the PRISMA statement. PLoS Med. 6(7) (2009) 1-7 DOI: 10.1371/journal.pmed.1000097

[4] S.K. Chung, X.W. Chan, P. Lanier, P. Wong. Associations between work-family balance, parenting stress, and marital conflicts during COVID-19 pandemic in Singapore (Manuscript) (2020) 1-35. DOI: 10.31219/osf.io/nz9s8.

[5] L.E. Roos, M. Salisbury, L. Penner-Goeke, E.E. Cameron, J.L. Protudjer, R. Giuliano, T. Afifi, K. Reynolds. Supporting families to protect 
child health: Parenting quality and household needs during the COVID-19 pandemic. Available at SSRN 3685933. 2020. DOI: 10.31234/osf.io/u5xzw

[6] N. Waddell, N.C. Overall, V.T. Chang, M.D. Hammond. Gendered division of labor during a nationwide COVID-19 lockdown: Implications for relationship problems and satisfaction. J Soc Pers Relat. (2020) 1-23. DOI: 10.1177/0265407521996476

[7] C. Günther-Bel, A. Vilaregut, E. Carratala, S. Torras-Garat, C. Pérez-Testor. A mixed-method study of individual, couple, and parental functioning during the state-regulated COVID19 lockdown in Spain. Fam. Process. 59(3) (2020). DOI: 10.1111/famp.12585

[8] A. Mikocka-Walus, M.A. Stokes, S. Evans, L. Olive, E. Westrupp. Finding the power within: Is resilience protective against symptoms of stress, anxiety, and depression in Australian parents during the COVID-19 pandemic?. J Positive Psych 2020. DOI: 10.31234/osf.io/v5gpm

[9] L.M. Vowels, K. Carnelley, R. FrancoisWalcott R. Successful negotiation of goal conflict between romantic partners predicts better goal outcomes during COVID-19: A Mixed Methods Study. 2020. DOI: 10.31234/osf.io/ydxwe

[10] S.L. Restubog, A.C. Ocampo, L. Wang. Taking control amidst the chaos: Emotion regulation during the COVID-19 pandemic. J. Vocat. Behav. $119 \quad$ (20200 ;111-6. DOI: 10.1016/j.jvb.2020.103440

[11] S.E. Hobfoll. Social and psychological resources and adaptation. Rev Gen Psychol. 6(4) (2002) 307-324. DOI: 10.1037/10892680.6.4.307

[12] L.L. ten Brummelhuis, A.B. Bakker. Staying engaged during the week: The effect of off-job activities on next day work engagement. J Occup Health Psychol. 17(4) (2012) 445-455. DOI: $10.1037 / \mathrm{a} 0029213$

[13] A.D. McEachern, T.J. Dishion, C.M. Weaver, D.S. Shaw, M.N. Wilson, F. Gardner. Parenting Young Children (PARYC): Validation of a selfreport parenting measure. J Child Fam Stud. 21(3) (2012) 498-511. DOI: 10.1007/s10826- 011-9503-y

[14] F. Gardner, S. Ward, J. Burton, C. Wilson. The role of mother-child joint play in the early development of children's conduct problems: A longitudinal observational study. Soc Dev 12(3) (2003) 361-378. DOI: 10.1111/14679507.00238

[15] L. Liang, H. Ren, R. Cao, Y. Hu, Z. Qin, C. Li, S. Mei. The effect of COVID-19 on youth mental health. Psychiatr Q. 91(3) (2020) DOI: $10.1007 / \mathrm{s} 11126-020-09744-3$

[16] E. Di Giorgio, D. Di Riso, G. Mioni, N. Cellini. The interplay between mothers' and children behavioral and psychological factors during COVID-19: an Italian study. Eur Child Adolesc Psychiatry 31 (2020) 1-2. DOI: 10.31234/osf.io/dgk7h

[17] J.P. Shonkoff, P.A. Fisher. Rethinking evidence-based practice and two-generation programs to create the future of early childhood policy. Dev. Psychopathol. 25 (2013) 16351653. DOI: $10.1017 /$ S0954579413000813

[18] A. Rahman, P.J. Surkan, C.E. Cayetano, P. Rwagatare, K.E. Dickson. Grand challenges: integrating maternal mental health into maternal and child health programmes. PLoS Med. 10(5) (2013) DOI: $10.1371 /$ journal.pmed.1001442

[19] L. Craig, B. Churchill. Dual-earner parent couples' work and care during COVID-19. Gend Work Organ. (2020) 1-24 DOI: 10.1111/gwao.12497

[20] M. Rutter. Resilience in the face of adversity: Protective factors and resistance to psychiatric disorder. Br J Psychiatry. 147(6) (1985) 598611. DOI: 10.1192/bjp.147.6.598

[21] J.G. Dyer, T.M. McGuinness. Resilience: Analysis of the concept. Arch. Psychiatr. Nurs. 10(5) (1996) 276-282. DOI: 10.1016/S0883-9417(96)80036-7

[22] J Torales, M. O’Higgins, J.M. Castaldelli-Maia, A. Ventriglio. The outbreak of COVID-19 coronavirus and its impact on global mental health. Int J Soc Psychiatry. 66(4) (2020) 317-320. DOI: 10.1177/0020764020915212

[23] N.K. Valtorta, M. Kanaan, S. Gilbody, S. Ronzi, B. Hanratty. Loneliness and social 
isolation as risk factors for coronary heart disease and stroke: systematic review and metaanalysis of longitudinal observational studies. Heart. 102 (2016) 1009-1016. DOI: 10.1136/heartjnl-2015-308790

[24] N. Leigh-Hunt, D. Bagguley, K. Bash, V. Turner, S. Turnbull, N. Valtorta, W. Caan. An overview of systematic reviews on the public health consequences of social isolation and loneliness. Public health. 152 (2017) 157-171. DOI: 10.1016/j.puhe.2017.07.035

[25] J. Gere, U. Schimmack. When romantic partners' goals conflict: Effects on relationship quality and subjective well-being. J Happiness Stud. 14(1) (2011) 37-49. DOI: 10.1007/s10902-011-9314-2 